\title{
MINIMALLY INVASIVE SURGERY FOR STRESS URINARY INCONTINENCE - MESH COMPLICATIONS
}

\author{
Vasil N. Iliev ${ }^{1}$, Irena T. Andonova ${ }^{2}$ \\ ${ }^{1}$ Department of Obstetrics and Gynaecology, Medical Faculty, Skopje, R. Macedonia \\ ${ }^{2}$ Department of Obstetrics and Gynaecology, OB Sibenik, Croatia
}

Corresponding Author: Vasil N. Iliev, Department of Obstetrics and Gynaecology, Medical Faculty, Skopje, R. Macedonia; E-mail: vilievtvt@gmail.com

\begin{abstract}
Currently, the most commonly performed surgeries for stress urinary incontinence (SUI) are mesh midurethral slings (MUS). They are minimally invasive outpatient procedures, and they are as effecttive as traditional suburethral slings, open retropubic colposuspension (Burch, Marshall-Marchetti), and laparoscopic retropubic colposuspension. They have a short operative time and fewer postoperative complications. In the paper we present results from a prospective study of 214 patients with SUI who underwent midurethral sling placement: 68 patients with retropubic slings (TVT) and 146 patients with transobturator slings (TVT-O) followed over 12 months. The operations were performed at the Department of Obstetrics and Gynaecology at the Medical Faculty, Skopje, R. Macedonia and at the Department of Obstetrics and Gynaecology, General Hospital, Sibenik, Croatia. All MUS placements (TVT and TVT-O) were performed by one surgeon (urogynaecologist) using the standard surgical technique and operative and postoperative protocol for those procedures. TVT and TVT-O meshes are polypropylene macroporous meshes produced by "Ethicon" We evaluated mesh complications related to the procedure (Table 1) and complications specific to the mesh (Table 2). In the article are presented the data from up-to-date literature related to the evaluated topic parallel to our results. We can conclude that all our findings on the evaluated groups are comparable with the data from competent literature. Instead of a conclusion we would like to suggest continuous follow-up of all minimally invasive procedures with midurethral slings placement for collecting experience of side-effects and complications and improving those procedures which are gold standard today in the treatment of SUI.
\end{abstract}

Key words: mesh, complication, stress incontinence, retropubic, transobturator.

Stress urinary incontinence (SUI) is a common disorder that affects a large number of women and their quality of life. SUI also has a significant socioeconomic impact. This disorder affects $6 \%$ to $35 \%$ of women and is characterised by an increase in intra-abdominal pressure that exceeds urethral closure pressure and results in involuntary leakage of urine. Symptomatic SUI of low grade (occasional or first grade of SUI - Green classification) may be treated conservatively. Candidates for surgical treatment are women with SUI grades two and three (Green), women who decline or have failed conservative treatment. Currently, the most commonly performed surgeries for SUI are mesh midurethral slings (MUS). They are minimally invasive outpatient procedures, and they are as effective as traditional suburethral slings, open retropubic colposuspension (Burch, MarshallMarchetti), and laparoscopic retropubic colposuspension. They have a short operative time and fewer postoperative complications $[1,2]$.

In a meta-analysis of 62 trials, the average success rate was over $80 \%$ with patient satis- 
faction rates over $87 \%$ [1]. A wide range of different mesh MUS in treatment of SUI results in a larger amount of data about complications which can be related to procedure and complications specific to the mesh.

We evaluated 214 patients with SUI who had had MUS placement (68 retropubic slings - TVT and 146 transobturator slings - TVT-O) during 12 months postoperatively. The operations were performed at the Department of Obstetrics and Gynaecology at the Medical Faculty, Skopje, R. Macedonia and at the Department of Obstetrics and Gynaecology, General Hospital, Sibenik, Croatia. All MUS placements (TVT and TVT-O) were performed by one surgeon (urogynaecologist) using the standard surgical technique and operative and postoperative protocol for those procedures. TVT and TVT-O meshes are polypropylene macroporous meshes produced by "Ethicon". We analysed complications related to procedure and complications specific to the mesh. In the article are presented data from up-to-date literature related to the evaluated topic together with results from our series.

Complications related to the procedure that are more common:

* Failure to correct incontinence

* New or worse urge to incontinence

* Voiding dysfunction

* Urinary tract infection

* Bladder and urethral perforation

* Vaginal perforation

* Vascular injuries

\section{Failure to correct incontinence}

The largest randomized controlled trial of retropubic compared to transobturator slings (597 subjects) reported objective success rates of $80.8 \%$ in retropubic sling group and $77.7 \%$ in transobturator sling group. At 24 months success rates remained similar: $77.3 \%$ and $72.3 \%$ with patient satisfaction rates $86.3 \%$ and $88.1 \%$ [3]. A systematic review of ten studies reporting 12 months outcomes for 1178 women after TVTsecure reported an overall subjective and objective cure rate of $76 \%$ [4]. They noted that postoperative incontinence severity was greater with the mini-sling than with the retropubic sling.

Our results: follow-up of outcomes after 12 months of 68 women with retropubic sling (TVT) and 146 women with transobturator sling
(TVT-O) showed an objective and subjective cure rate of $81.1 \%$ and $84.3 \%$ respectively. We noted better results in the TVT-O group, which is probably a consequence of longer surgical practice, experience, with this tension-free vaginal tape procedure.

\section{New or worse urinary incontinence}

Postoperative urge symptoms have been reported in $6 \%$ to $25 \%$ of women after retropubic slings and $6 \%$ after transobturator slings [1]. Postoperative urge incontinence is treated with conservative measures or/and medications (anticholinergics).

Our results: in our series we registered 3 women $(5 \%)$ with urge symptoms/incontinence after retropubic slings (TVT) and they were treated with medication. In the series with transobturator slings we had no case of new or worse urinary incontinence.

\section{Voiding dysfunction}

Short-term voiding dysfunction that manifests as incomplete bladder emptying is relatively common $(16 \%$ on day 0 or 1 after a retropubic sling). Long-term voiding dysfunction is uncommon. The rates of voiding dysfunction are lower with transobturator slings. Voiding dysfunction is typically managed with catheterrization and usually resolves spontaneously. When this does not happen, surgical release of the sling may be considered. In a series of 600 subjects, 17 had transvaginal release for urinary retention [5]. Sling release is usually successful in relieving voiding dysfunction but can result in SUI recurrence. A study by Laurikainen et al. [6] of 50 women who had sling release reported that urinary retention did not completely resolve in 4 patients $(12 \%)$.

Our results: in our series of 68 TVT and 146 TVT-O slings followed for 12 months we had 3 cases of urinary retention in the retropubic sling group (5\%) and one case in the transobturator group, all resolved spontaneously after catheterization. We recorded no case with longterm voiding dysfunction so the we did not have surgical release of mesh for voiding dysfunction.

\section{Urinary tract infection}

Urinary tract infection is a common complication after MUS - up to $34 \%$ of patients 
within the first three postoperative months. [7] Urinary tract infection is more common in patients with intra- and/or postoperative catheterization (retropubic slings).

Our results: In our series of 68 TVT we noted 7 patients $(10 \%)$ and in the TVT-O group (146 women) there were only 2 cases of UTI $(1 \%)$. In this evidence the contribution of surgical procedure (urinary catheterization) on the frequency of UTI is clearly evident.

\section{Bladder and urethral perforation}

Intraoperative bladder perforation is the most common complication of retropubic MUS placement. A retrospective review of all MUS revealed 44 bladder perforations from 2339 retropubic slings (2\%) and 4 from 794 transobturator slings $(0.5 \%)$. Two urethral perforations were also revealed from retropubic slings $(0.08 \%)$ and none from transobturator slings [8].

Our results: In our series of retropubic slings we had 1 case $(1.4 \%)$ of bladder perfor ation and none in the transobturator group. We had no urethral injury in our evaluated MUS-s.

\section{Vaginal perforation}

Transobturator slings have a higher risk of vaginal perforation compared with retropubic slings (the course of the sling is closer to the anterior vaginal fornices). In a series of 500 transobturator MUS procedures, vaginal perforation has been reported in $0.4 \%$, and $1.3 \%$ of subjects [9]. The vaginal sulci should be inspected and palpated after insertion of the trocars, and if a perforation is identified, the trocars should be removed and replaced in the appropriate position.

Our results: In our transobturator MUS group (146 women) we had one case with perforation of the vaginal fornice on one side (left) and it was resolved intraoperatively and the vaginal wall was sutured.

\section{Vascular injuries}

Vascular injuries can occur with the blind passage of trocars and occur more commonly with retropubic slings than with transobturator slings. Injuries may involve the paravesical veins, obturator, external iliac, femoral, inferior epi- gastric or circumflex vessels. A meta-analysis of randomized, controlled trials involving MUS surgeries reported a total of 7 pelvic haematomas out of 479 women (1.4\%) [10]. Haemorrhages (defined as $>500 \mathrm{ml}$ of blood loss) and/or blood transfusions have been reported in approximately $2.5 \%$ of cases of retropubic MUS [11].

Excessive bleeding is usually venous and can often be managed intraoperatively with direct pressure on the paraurethral or retropubic areas. Venous injury typically results in self-limited slowly expanded retropubic haematoma, which may result in symptoms of bladder compression (suprapubic pain, urinary urgency, and urinary frequency) and/or signs of significant blood loss (tachycardia, hypotension, anaemia, oliguria). Abdominal and bimanual pelvic examination may reveal a palpable mass in the suprapubic or retropubic spaces. Diagnostics may need to be supported by sonography or computed tomography. The study by Flag et al. [12] on 14 women who underwent sonographic evaluation of retropubic haematoma predicted the severity of symptoms: $<100 \mathrm{ml}$ (rarely symptomatic), 100-200 ml. (moderate pain) and $>300 \mathrm{ml}$. (severe pain requiring surgical evaluation).

Our results: In the series of 68 retropubic slings we had 2 patients $(0.3 \%)$ with retropubic haematoma with moderate pain who were treated conservatively. We noted no vascular injury in the group with transobturator slings.

\section{Bowel injury}

Women with prior abdominal or pelvic surgery and women who have an abdominal or inguinal hernia seem to have an increased risk of bowel injury during sling placement. A transobturator MUS may be preferable for these patients. Bowel perforation is a surgical emergency. Women with severe or persistent abdominal pain after retropubic MUS placement should be evaluated for bowel injury. A survey of surgeons who performed over 12,000 TVT procedures reported 3 bowel perforations [13].

Our results: In both MUS groups in our series we had no bowel injury. 
Complications related to the PROCEDURE (Our results)

\begin{tabular}{|l|c|c|}
\cline { 2 - 3 } \multicolumn{1}{c|}{} & TVT $(\mathrm{n}=68)$ & TVT-O $(\mathrm{n}=146)$ \\
\hline Overall satisfaction rate & $81.1 \%$ & $84.3 \%$ \\
\hline New or worse urinary incontinence (urge incont.) & $3(4.4 \%)$ & $/$ \\
\hline Voiding dysfunction (urinary retention) & $3(4.4 \%)$ & $1(0.6 \%)$ \\
\hline Urinary tract infection & $7(10 \%)$ & $2(1.3 \%)$ \\
\hline Vaginal perforation & $/$ & $1(0.6 \%)$ \\
\hline Vascular injuries (retropubic haematoma) & $2(2.9 \%)$ & $/$ \\
\hline Bowel injury & $/$ & $/$ \\
\hline
\end{tabular}

Complications of midurethral sling surgeries specific to mesh

Complications that are specific to the use of mesh in midurethral slings include:

* Mesh exposure in the vagina

* Mesh erosion into the bladder or urethra

* Pain

* Dyspareunia

* Infection

Several differences in complication rates between retropubic and transobturator approaches are delineated above (increased voiding dysfunction and urinary tract infections after retropubic slings, increased neurological symptoms after transobturator slings).

\section{Vaginal mesh exposure (erosion)}

In the series of 241 women who underwent TVT placement, $0.4 \%$ experienced vaginal mesh erosion [14]. Common symptoms of vaginal mesh exposure include visible or palpable mesh in the vagina, vaginal bleeding, vaginal discharge, postcoital spotting and urinary tract infection. The diagnosis of mesh exposure is made with visual inspection of the vagina.

Management of vaginal exposures varies according to the extent of the erosion and the severity of the symptoms. Initial management may be conservative, with vaginal oestrogen therapy. If symptoms persist and/or the patient or her partner can feel the sling, surgical treatments may be offered (excision of the exposed portion of the mesh through a vaginal approach - rarely it may result in recurred SUI).

Our results: In our series of 68 retropubic slings we had 2 cases $(2.9 \%)$ and 1 patient $(0.6 \%)$ of the 146 transobturator mesh placement group with vaginal mesh erosion.

Mesh erosion into the bladder or urethra

Mesh erosion into the bladder or urethra is uncommon. One series of 3747 women with mesh MUS $3(0.08 \%)$ underwent reoperation for urethral mesh erosion [8]. Bladder erosion typically presents several weeks to months postoperatively as urinary urgency, haematuria or bladder stones. They are best diagnosed with cystoscopy. There are a variety of management options, including transurethral cystoscopic resection; transvaginal or transabdominal reconstructive procedure in cases where a fistula is present.

Our results: In our series of 214 MUS slings we had no bladder or urethral mesh erosion.

\section{Pain}

In a study that randomly assigned women to retropubic or transobtrator slings, pain $>6$ weeks after surgery was self-reported by $2 \%$ of subjects in each group. Chronic pain was reported in $7.5 \%$ of 241 women who underwent retropubic MUS placement [14].

The groin pain that can occur with transobturator MUS is typically felt deep within the muscles in the groin area and is exacerbated when the patient abducts or adducts her legs. Groin pain occurs in approximately $12 \%$ to $16 \%$ of women after transobturator procedure, but this usually resolves by 6 weeks. Depending upon the severity and duration, pelvic pain may be treated with expectant management, medical therapy or pelvic physical therapy.

Our results: We had acute (first month postoperative) $1 \%$ reporting pain in the retropubic sling group and $6 \%$ in the transobturator group.

\section{Dyspareunia}

Dyspareunia has been reported in $1 \%$ to $9 \%$ of women after transobturator sling placement [15]. Postoperative dyspareunia after retropubic MUS placement has not been reported in the absence of mesh erosion. 
Our results: We noticed dyspareunia in 2 cases $(1.3 \%)$ after transobturator mesh placement.
All were managed conservatively and resolved spontaneously within the follow-up period.

Table 2

Complications SPECIFIC TO MESH (Our results)

\begin{tabular}{|l|c|c|}
\cline { 2 - 3 } \multicolumn{1}{c|}{} & TVT $(\mathrm{n}=68)$ & TVT-O $(\mathrm{n}=146)$ \\
\hline Vaginal mesh exposure (erosion) & $2(2.9 \%)$ & $1(0.6 \%)$ \\
\hline Mesh erosion in bladder or urethra & $/$ & $/$ \\
\hline Pain & $1(1.4 \%)$ & $8(5.4 \%)$ \\
\hline Dyspareunia & $/$ & $2(1.3 \%)$ \\
\hline Vaginal perforation & $/$ & $2(1.3 \%)$ \\
\hline
\end{tabular}

\section{Conclusion}

Complication rates with MUS are low and generally fewer than the complications with previous traditional continence surgeries. Complication rates specific to mesh are low. Mesh MUS are a low mesh load and the amount of mesh near the surface of the vagina is minimal. The meshes have rapidly improved and adapted and remain the current standard of surgical care for SUI.

\section{REFERENCES}

1. Ogah J, et al. Minimally invasive synthetic suburethral sling operations for stress incontinence in women. Cochrane Database Syst Rev. 2009.

2. Ward K, et al. A randomized trial of colposuspension and tension-free vaginaltape(TVT) for primary genuine stress incontinence.Neurourol.Urodyn. 2010; 19: 386.

3. Richter HE. Retropubic versus transobturator midurethral slings for stress incontinence. $\mathrm{N}$ Engl $\mathrm{J}$ Med. 2010; 362: 2066.

4. Walsh CA, et al. Secur mini-slings for stress urinary incontinence. a review of outcomes at 12 months. BJU Int. 2011; 108: 652.

5. Klutke $\mathrm{C}$, et al. urinary retention after tension-free vaginal tape procedure: incidence and treatment. Urology. 2001; 58: 697.

6. Laurikainen E, et al. A nationwide analysis of transvaginal tape release for urinary retention after tension-free vaginal procedure. Int Urogynecol J Pelvis Floor Disfunct. 2006; 17: 111.

7. Anger JT, et al. Complications of sling surgery among females. Obstet Gynecol. 2007; 109: 707.

8. Nguyen JN, et al. Periopertive complications and reoperations after incontinence and prolapse surgeries using prosthetic implants. Obstet Gynecol. 2012; 119: 539.

9. Tomassino $\mathrm{K}$, et al. Transobturator tapes for stress urinary incontinenece reults of the Austrian registry. Am J Obstet Gyncol. 2007; 197: 634.
10. Novara G, et al. Updated systematic review and meta-analysis of the comparative data of colposuspensions and midurethral tapes in the surgical treatment of female stress urinary incontinence. Eur Urol. 2010; 58: 218.

11. Kobashi KC, et al. Perioperative complications: the first 140 polypropylene pubovaginal slings. J Urol. 2003; 170: 1918.

12. Flock F, et al. Hemorrhagic complications associated with tension-free vaginal tape procedure. Obstet Gynecol. 2004; 104: 989.

13. Agostini A, et al. Immediate complications of tension-free vaginal tape (TVT) results of French survey. Eur J Obstet Gynecol Repro Biol. 2006; 124: 237.

14. Abouassaly R. et al. Complications of tension-free vaginal tape surgery: a multi-institutional review. BJU Int. 2004; 94: 110.

15. Neuman M, et al. TVT-obturator: short-term data on an operative procedure for the cure of female stress incontinence performed on 300 patients. Eur Urol. 2007; 51: 1083.

Резиме

\section{МИНИМАЛНО ИНВАЗИВНИ ХИРУРШКИ ПРОЦЕДУРИ \\ ЗА СТРЕС ИНКОНТИНЕНЦИЈА \\ НА УРИНАТА † КОМПЛИКАЦИИ ОД СЛИНГ-ПРОЦЕДУРИ}

\section{Васил Н. Илиев ${ }^{1}$, Ирена Т. Андонова ${ }^{2}$}

${ }^{1}$ Клиника за гинекологија и акушерство, Медицински факултет, Универзитет „Св. Кирил и Методиј“, Скопје, Р. Македонија ${ }^{2}$ Оддел за гинекологија и акушерство, ОБ Шибеник, Р. Хрватска

Стрес инконтиненцијата на урина (СИУ) е често нарушување што зафаќа од $6 \%$ до $35 \%$ жени и има значаен негативен ефект врз квалитетот на животот, како и значително социо- 
економско влијание. СИУ се карактеризира со неволно испуштање урина во тек на зголемен интраабдоминален односно интравезикален притисок што го надминува интрауретралниот притисок. Постојат голем број хируршки корективни процедури, а актуелно најчесто применувани интервенции за корекција на СИУ се субуретрални слинг-процедури со поставување хетероматеријал како супституциона субуретрална интегрална потпора. Тоа се минимално инвазивни хируршки процедури на база на еднодневна хоспитализација и се еднакво или поефикасни од некои традиционални корективни интервенции (колпосуспензија по Burch, Marshall-Marchetti, лапароскопска ретропубична колпосуспензија). Тоа се интервенции што се изведуваат за кратко време, пациентките брзо закрепнуваат и имаат помалку компликации (интра и постоперативни). Во трудот се презентирани најактуелни податоци од стручната литература во однос на компликации поврзани со процедурата на хируршката интервенција (наши резултати: Табела 1), како и компликации специфични за имплантираната мрежичка (наши резултати: Табела 2) и тие се компарирани со наши резултати на студија од 214 пациентки поделени во група на ретропубичен слинг (ТВТ) со 68 случаи и група со трансоптураторен слинг (ТВТ-О) со 146 пациентки следени 12 месеци. Интервенциите се изведени од страна на еден оператор (урогинеколог) на Клиниката за гинекологија и акушерство, Медицински факултет, Скопје, Р. Македонија, и на Одделот за гинекологија и акушерство при Општата болница во Шибеник, Р. Хрватска. Сите евалуирани параметри од испитуваните групи се компарабилни со публицираните резултати од компетентни студии во стручната литература. Наместо заклучок, сугерираме понатамошно следење на сите минимално инвазивни хируршки процедури за третман на СИУ за да се редуцираат ад максимум сите несакани ефекти и компликации од нив, кои денес претставуваат златен стандард за третман на ова често нарушување.

Клучни зборови: слинг-мрежички, компликации, стрес инконтиненција, ретропубични, трансоптуратор. 